\title{
Malta and Sicily Joined by Geoheritage Enhancement and Geotourism within the Framework of Land Management and Development
}

\author{
Chiara Cappadonia ${ }^{1}$ (D), Paola Coratza ${ }^{2, *}$, Valerio Agnesi ${ }^{1}$ and Mauro Soldati ${ }^{2}$ (I) \\ 1 Department of Earth and Sea Sciences, University of Palermo, Via Archirafi 22, 90123 Palermo, Italy; \\ chiara.cappadonia@unipa.it (C.C.); valerio.agnesi@unipa.it (V.A.) \\ 2 Department of Chemical and Geological Sciences, University of Modena and Reggio Emilia, Via Campi 103, \\ 41125 Modena, Italy; mauro.soldati@unimore.it \\ * Correspondence: paola.coratza@unimore.it; Tel.: +39-059-2055884
}

Received: 18 May 2018; Accepted: 5 July 2018; Published: 9 July 2018

\begin{abstract}
Malta and Sicily, which lie at the centre of the Mediterranean Sea, share a long history and have unique geological and geomorphological features which make them attractive destinations for geotourism. In the framework of an international research project, a study for the identification, selection and assessment of the rich geological heritage of Malta and Sicily was carried out, aiming to create a geosite network between these islands. Based on the experience and outputs achieved in previous investigations on geoheritage assessment carried out in various morpho-climatic contexts, an integrated methodology was applied for the selection, numerical assessment and ranking of geosites. The selection phase was based on three main criteria-scientific, additional and use values - and led to the establishment of a list of 42 geosites (20 in Malta and 22 in Sicily). Besides being spectacular and attractive for tourists, these sites represent the main geomorphological contexts and the various stages of regional morphogenesis of the study areas. The sites selected were assessed quantitatively and ranked according to management and tourism criteria. The results provide both the necessary basic knowledge for joint conservation actions and policies in Malta and Sicily and the elements for creating a link between Malta and Sicily through geoheritage appraisal and tourism development.
\end{abstract}

Keywords: geoheritage; geotourism; Malta; Sicily; Mediterranean Sea

\section{Introduction}

Tourism, in particular geotourism, is a sector in continuous expansion in the management, use and enhancement of geological heritage. As a concept in Earth Sciences, the term "geotourism" has been in common usage since the mid-1990s and there has been much discussion about its definition (see [1-7]). Regardless of different definitions and terminologies, the promotion of geological and geomorphological features in combination with other natural and cultural features, is the main object of this kind of tourism. Recently, the ever growing attention to environmental issues in the tourist market, including geological and geomorphological topics, is reflected in numerous geotourism activities and products available worldwide (e.g., [5] and references therein; [8-14]).

In this perspective, geotourism can be a crucial resource in many countries. This applies in particular to the Maltese Islands and Sicily, where a rich cultural and natural heritage and outstanding aesthetic qualities of coastal landscapes make up the main tourist attractions. Therefore, it should be a priority for tourism to preserve the landscape where development can be carried out respecting the natural environment and cultural context according to the principles of "sustainability" $[15,16]$. 
The research illustrated in this paper was carried out within the framework of the international project entitled RE.MA.SI. (Malta-Sicily Ecological Cross-border Networks) funded by the Italy-Malta 2007-2013 Cross-Border Cooperation Programme of the European Commission, within the Priority axis "Environment, Energy and Risk Prevention", which aims to improve the quality of life for present and future generations on the basis of sustainable development of the potential resources of cross-border areas. The overall goal of the Programme was the strengthening of attractiveness and competitiveness of cross-border areas through conservation and appraisal of areas of natural interest by exchanging information and good management, and connecting sites of ecological and environmental interest.

The RE.MA.SI. Project included our pilot study and aimed to select and assess sites of geological interest in two coastal areas located in southern Sicily and in the north-western part of the Island of Malta. In particular, the main objectives of our research were: (i) to select and assess sites of geological interest within the study areas that, besides being spectacular and attractive for tourists, can offer significant elements that help people to appreciate the geomorphological history of both islands, highlighting their environmental similarities and differences; (ii) to identify the most significant geosites, in terms of tourism promotion and management.

\section{Malta and Sicily: Similarities and Differences}

Malta and Sicily share a long history. The earliest human settlements in Malta date back to the Neolithic Age and suggest the presence of peoples from the south-eastern part of Sicily. A long tradition of trade contacts between Malta and Sicily is witnessed by pottery artefacts linked to the Stentinello culture, first encountered in the 6th millennium BC in the Uzzo cave in Sicily and similarly in Malta at the Skorba temple site [17].

Later on, Malta and Sicily were both conquered by the Phoenicians, Carthaginians, Romans, Vandals, Byzantines and Arabs [18-22]. The Normans seized Malta around 1091 and the archipelago became part of the Kingdom of Sicily, which also covered most of present-day southern Italy. The Maltese archipelago remained formally a feudal dependency of the Kingdom of Sicily even when, in 1530, it was given to the military monastic order of the "Knights Hospitallers" for a perennial rent consisting in the symbolic annual feudal tax of a falcon. From that moment, the order will be known as the "Knights of Malta". Malta's political dependency on Sicily ended in 1798 when Napoleon's army conquered the island and, subsequently, with the final inclusion of the Maltese archipelago into the British Empire [23].

In addition to about 7000 years of shared history, Malta and Sicily are characterised by distinctive environmental and climatic similarities, as they are both placed in the southern part of the Mediterranean Sea. The climate of both islands is typically Mediterranean and during the Quaternary they experienced similar climate history. They are located within a key climatic belt in the central Mediterranean, although Holocene climate history shows different palaeo-hydrological patterns to the north and south of this belt [24].

Malta and Sicily have many geological similarities since they form a spur on the northern edge of the African continental plate that includes SE Sicily, the Pelagian Islands, eastern Tunisia, and the north-western Libyan shelf. During the last million years, both islands have alternately been physically linked to each other and to the Italian peninsula $[25,26]$, becoming extraordinary sites for understanding the evolution of Pleistocene fauna [27]. Because of the cycles of advancing and retreating of continental glaciers and dramatic sea-level fluctuations, various species of mammals migrated in alternate directions across land bridges. Further isolation induced many considerable morphological adaptations of the fauna.

During the Last Glacial Maximum (LGM), ca. 20 ka ago, the paleogeography of the Mediterranean was very different from today: the sea level was about $130 \mathrm{~m}$ below the present one and the Italian peninsula was much larger than it is today (Figure 1). The reconstructed palaeo-shoreline indicates that a wide strip of land about $38 \mathrm{~km}$ wide and $105 \mathrm{~km}$ long connected the south-eastern corner of 
Sicily and the Malta-Gozo insular system. During the late Pleistocene and Holocene, the sea level was rising and at $12.4 \mathrm{ka}$ cal BP, Sicily and Malta were separated by about $62 \mathrm{~km}$ of sea [19,20].

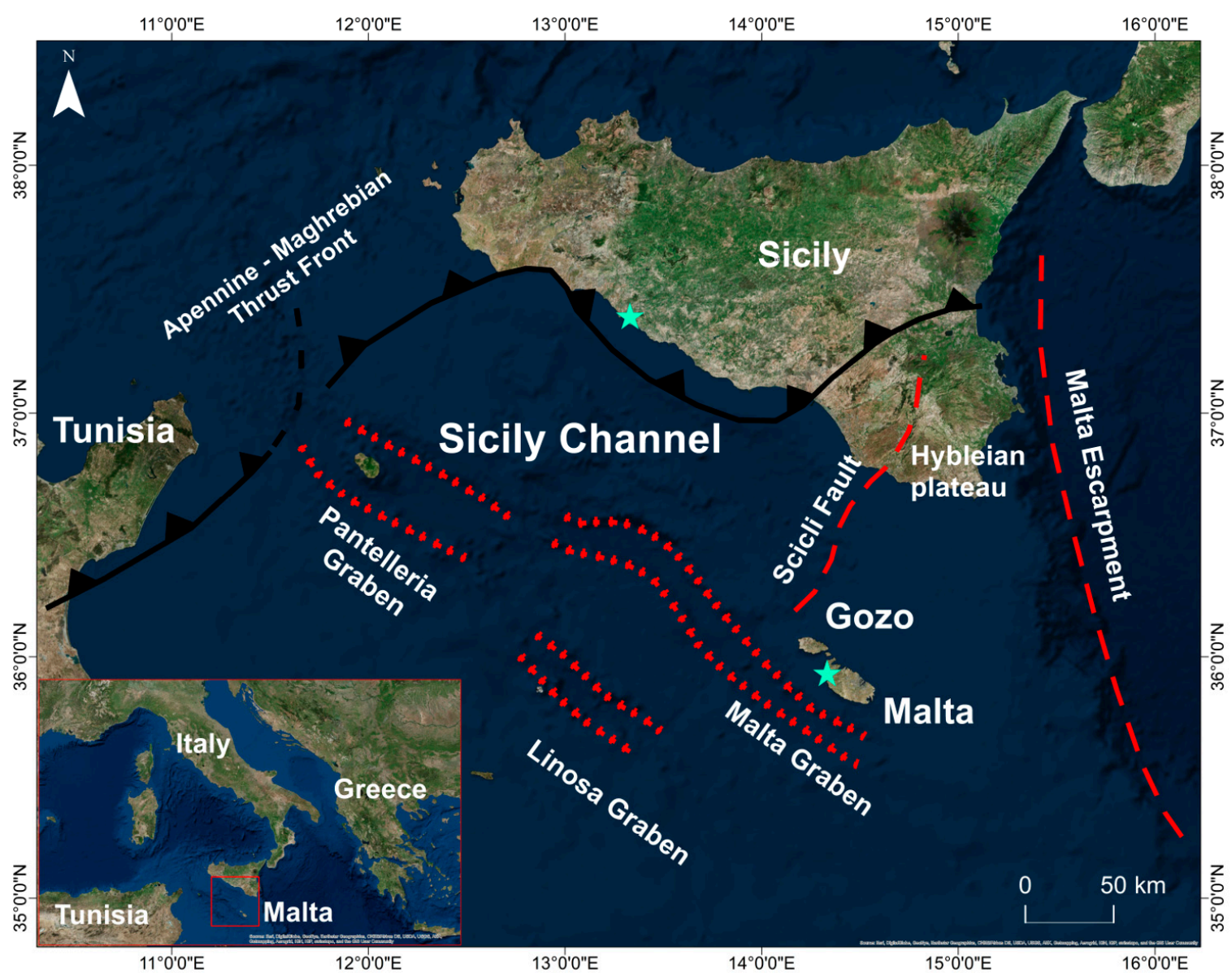

Figure 1. Location map of the study areas showing the principal structural features (cf. [25,27]).

The existence of a long-lasting "bridge" between Malta and Sicily has led to the convergence of the Pleistocene vertebrate fauna of the two islands, both characterised by the presence of dwarf elephants. In fact, in Sicily and in the Maltese Islands a succession of different animal populations occurred over the last million years. They reached Sicily and Malta when the islands were connected because of the eustatic oscillations of sea level. Among the fossil remains that characterise Quaternary fauna, including large mammals, there are elephants originating in Asia. These populated continental Europe as far as Sicily and Malta. Biogeographic isolation due to insularity determined the development of dwarf-sized mammals, which are a palaeontological peculiarity of Sicily, Malta, and some other islands of the Mediterranean Sea [28].

From a geographic and physical standpoint, Sicily was characterised by a mountain range extending along the northern coast and extensive hilly areas located south of the chain. One of the effects of the decrease of sea level was strong fluvial incision with a consequent deepening of fluvial valleys and an increase in slope processes [29]. On the other hand, the Maltese Islands were characterised by a geological structure similar to that of the Hyblaean shelf, which finally emerged in the late Miocene. After this period, a stationary phase started, followed by tectonic extension events that produced a horst and graben structure, which still characterises the northern sector of the Maltese archipelago. For this reason, Plio-Pleistocene deposits, made up of colluvium and materials filling karst fissures and caves, are very scarce. From a geological viewpoint, Malta and Sicily are still linked by a smaller but continuous submerged bridge, named the Malta plateau or the Hyblean platform, 
since it links the Hyblean plateau of south-eastern Sicily to geological formations of the same age in Malta [25,30,31] (Figure 1). A common heritage from the paleo-geographic evolution of the two regions can therefore be found in different sectors of the islands.

The Malta archipelago and Sicily include a rich variety of outstanding elements of natural and cultural interest and are representative of the Mediterranean region. At present, both islands attract many tourists, also thanks to their mild Mediterranean climate, characterised by warm, dry summers, relatively wet autumns and short, mild winters. Nevertheless, their environmental potential is not fully utilised for attracting tourists and visitors. In particular, the short distance between these two islands could allow the creation of common itineraries, jointly offered and managed by Italian and Maltese institutions. However, although Malta and Sicily show remarkable commonalities, they also display significant differences that have influenced their environmental evolution and cultural development through time, which may offer added value to any joint utilisation and enhancement initiatives.

Within this research, attention was focused on two coastal areas, located in southern Sicily and in the north-western part of the Island of Malta, showing environmental features that can attract tourists to their spectacular landscapes. They host natural reserves showing peculiar types of flora and fauna, remarkable archaeological and/or historical sites and spectacular panoramic views (Figure 1). From a geological point of view, the rocks cropping out in the study areas (Miocene to Pliocene in age) have comparable lithological characteristics and show stratigraphic relationships. Besides having a series of geological commonalities, the study areas are characterised by differences mainly related to their recent evolution. In Malta, the intense tectonic stresses occurring during the Neogene and Quaternary have deeply conditioned landscape evolution, giving rise to a sequence of horsts and grabens, morphologically highlighted by alternations of ridges and valleys [31-33] and low thicknesses of the Plio-Pleistocene deposits. In Sicily, due to the post-LGM marine regression phase, down-cutting processes, deepening of valleys and denudation processes prevailed.

\subsection{Malta Study Area}

The Maltese study area (GEOMAL), located in the north-west of the island, includes a coastal stretch of about $25 \mathrm{~km}$ in length covering the area from Marfa Ridge, to the north, to the promontory of Ras ir-Raheb, to the south (Figure 2). The NW coast of Malta is sparsely inhabited, but is highly visited for recreational purposes by both locals and tourists due to the spectacular scenery of the coastal landscapes. The area displays important rural, vernacular and military heritage elements and hosts unique ecological systems, which form part of the list of Natura 2000 sites of international importance. Cultural features ranging from long dry stone walls and rural structures, to cart-ruts of unknown age and tombs dating from to the Classical period, enrich the area's interest making it both a cultural landscape and valuable tourist attraction [34].

National and EU authorities have recognized the importance of this area, which forms part of a larger Natura 2000 site. In 2007, the swath of land extending of about $7 \mathrm{~km}$ in length, from Manikata and Ghajn Tuffieha to Anchor Bay was turned into a protected area named Park tal-Majjistral (Il-Majjistral Nature and History Park), Malta's first National Park (Figure 2). Due to its high landscape value, since 1998 the area has also been included in the UNESCO World Heritage Tentative List. 


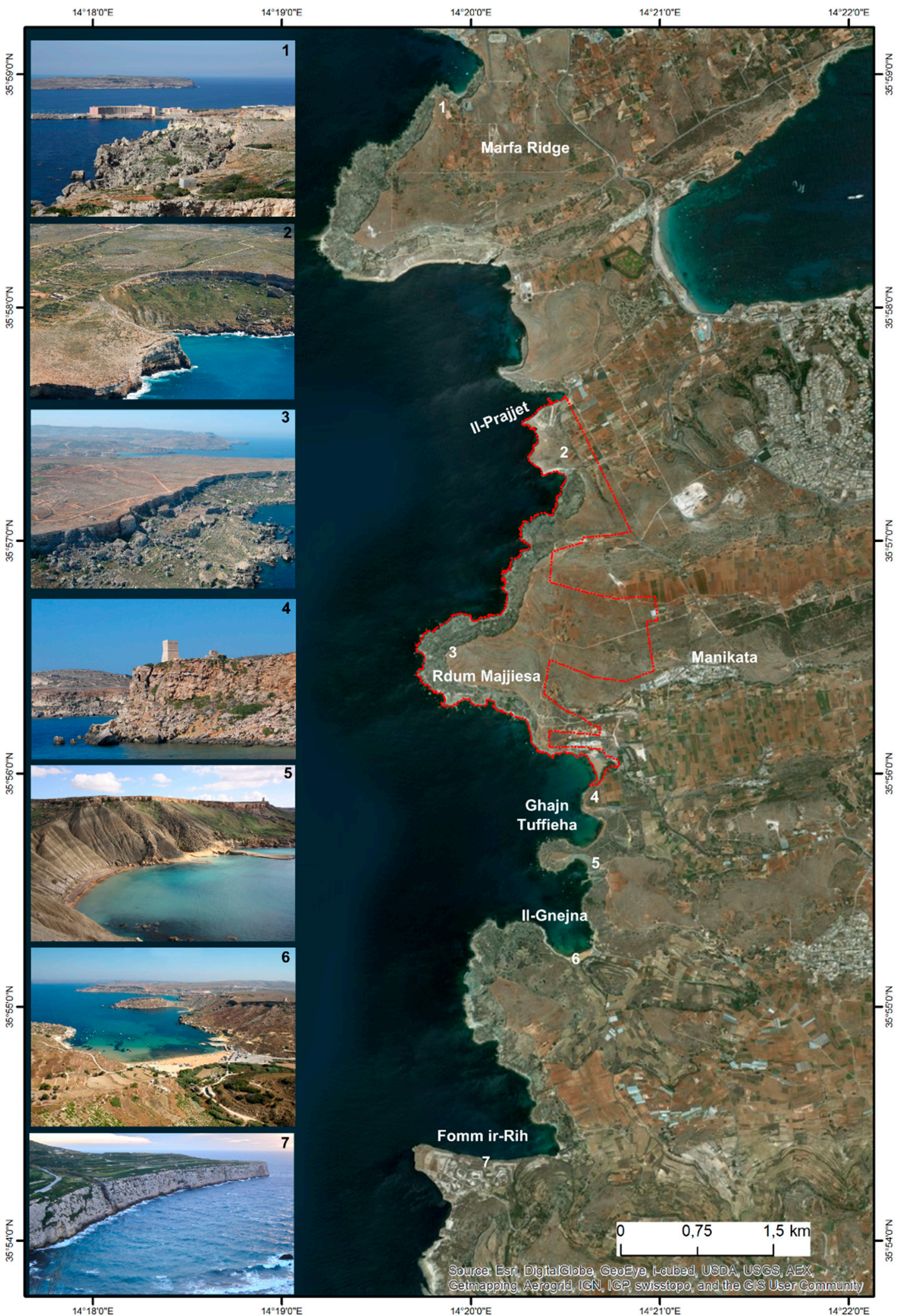

Figure 2. Outstanding geomorphological features of Malta study area (GEOMAL): (1-3) areas affected by block sliding favoured by the superimposition of Upper Coralline Limestone on Blue Clays; (4) Upper Coralline Limestone steep cliff with a watchtower on top, dating from 1637; (5) badland topography on a steep Blue Clay slope; (6) pocket beach; (7) the Great Fault scarp, one of the most significant structural features of the island. Red dashed-line delimits Il-Majjistral Nature and History Park boundary. 
The Maltese Islands are predominantly composed of marine sedimentary rocks, mainly limestone with subsidiary marls and clays, of Oligo-Miocene age with sporadic occurrences of Quaternary deposits in some areas [35-38]. In the study area, the Blue Clay Formation (Middle Miocene), formed mainly by marls and clays, 20 to $70 \mathrm{~m}$ thick, and the Upper Coralline Limestone Formation (Upper Miocene), a unit characterised by massive and resistant grey limestones reaching a maximum thickness of $175 \mathrm{~m}$, are dominant. This is reflected in the characteristic landscape of the area, controlled by the structural setting - the aforementioned series of ENE-WSW horst and graben systems-the lithology and the resulting selective erosion [33]. Structural landforms include structural platforms and scarps remodelled by coastal erosion and/or gravitational processes occurring mainly within the Upper Coralline Limestone Formation. Gravity-induced slope landforms and processes are widespread on the NW coast of the island. The different mechanical behaviour and diverse hydrogeological conditions of the outcropping rock types have induced the occurrence of various types of landslides: lateral spreading, rock falls, block slides and earth flows $[31,35,39,40]$. The main coastal features of the study area are represented by the succession of headlands, dominated by steep cliffs, some reaching $100 \mathrm{~m}$ in height, and bays with small pocket beaches at their heads. This coastline pattern is strictly linked with the structural setting of the island. Headlands and bays have developed in correspondence with horst and graben, respectively [33,41]. Due to the overall dynamics of the area and the present morpho-climatic conditions, fluvial landforms are quite scarce in the study area. However, the V-shaped small dry valleys in the Upper Coralline Limestone are particularly interesting: they are erosional relict features of former pluvial conditions and extensive groundwater sapping. Other landforms caused by running water are large valley beds, alluvial/colluvial cones, consisting of Quaternary sediments transported and deposited both through the action of water and through gravitational processes, and badlands shaped in the steep Blue Clay slopes bare of vegetation cover. Karst landforms are especially developed and widespread in the area. Small-scale surface features, like highly irregular and rugged shapes, which characterise the limestone plateau, are common whereas just three sinkholes have been observed in the area. The main man-made landscape modifications are related to agricultural and tourist activities. The landscape is mainly dominated by terraced fields retained by dry stone walls, used as agricultural land at both coastal and inland locations [42]. Even if Malta is an important tourist destination, the study area still remains quite pristine and tourism activities have not had a high impacted, apart from a few tourist structures located along the coast.

\subsection{Sicily Study Area}

The Sicilian study area (GEOSIC) is located on the southern coast of Sicily and stretches for about $20 \mathrm{~km}$ in a NW-SE direction from Seccagrande up to Giallonardo (Figure 3). The importance of this area has been recognised by regional and EU authorities as it is part of a larger Site of Community Importance (SCI), named "Foce del Magazzolo, Foce del Platani, Capo Bianco, Torre Salsa". GEOSIC contains nature-oriented reserves, cultural and tourist itineraries in the Mediterranean scrub and archaeological sites, such as the Greek ruins of Eraclea Minoa: a spectacular archaeological site built in the mid-6th century BC near Selinunte on a white cliff above a long and fine beach near the River Platani mouth which, together with the surrounding long sandy beaches and dunes, was turned into a nature reserve in 1984, covering an area of over 200 hectares of land. The Torre Salsa Reserve, located in the south-eastern part of the study area, extends along an over 750 hectare stretch of coastline (Figure 3).

As a result of long-term geological and geomorphological processes, this sector of Sicily is characterised by a large variety of landforms that make this part of the island unique.

The GEOSIC area is characterised by Tertiary and Quaternary rocks. The outcropping sequence includes several types of rocks: calcarenites and sands (Agrigento Formation, Pleistocene), clayey marls (Monte Narbone Formation and "trubi", Pliocene), gypsum (gypsum arenites of the Pasquasia Formation and salts of the Cattolica Formation, Messinian), clays (Serravallian and Tortonian deposits). 
Their stratigraphic succession has been modified by recent tectonic activity that have sometimes reversed their stratigraphic order. They have also been strongly shaped by morphogenetic processes.

The geomorphological evolution of the area is influenced by the lithology and the eustatic variations of the sea level, which are strictly related to a sea level rise since the upper Pleistocene. The inland part is characterised by a series of slightly sloped fluvial and marine terraces, frequently cut in their upper part by very wide, long gullies and V-shaped valleys [43].

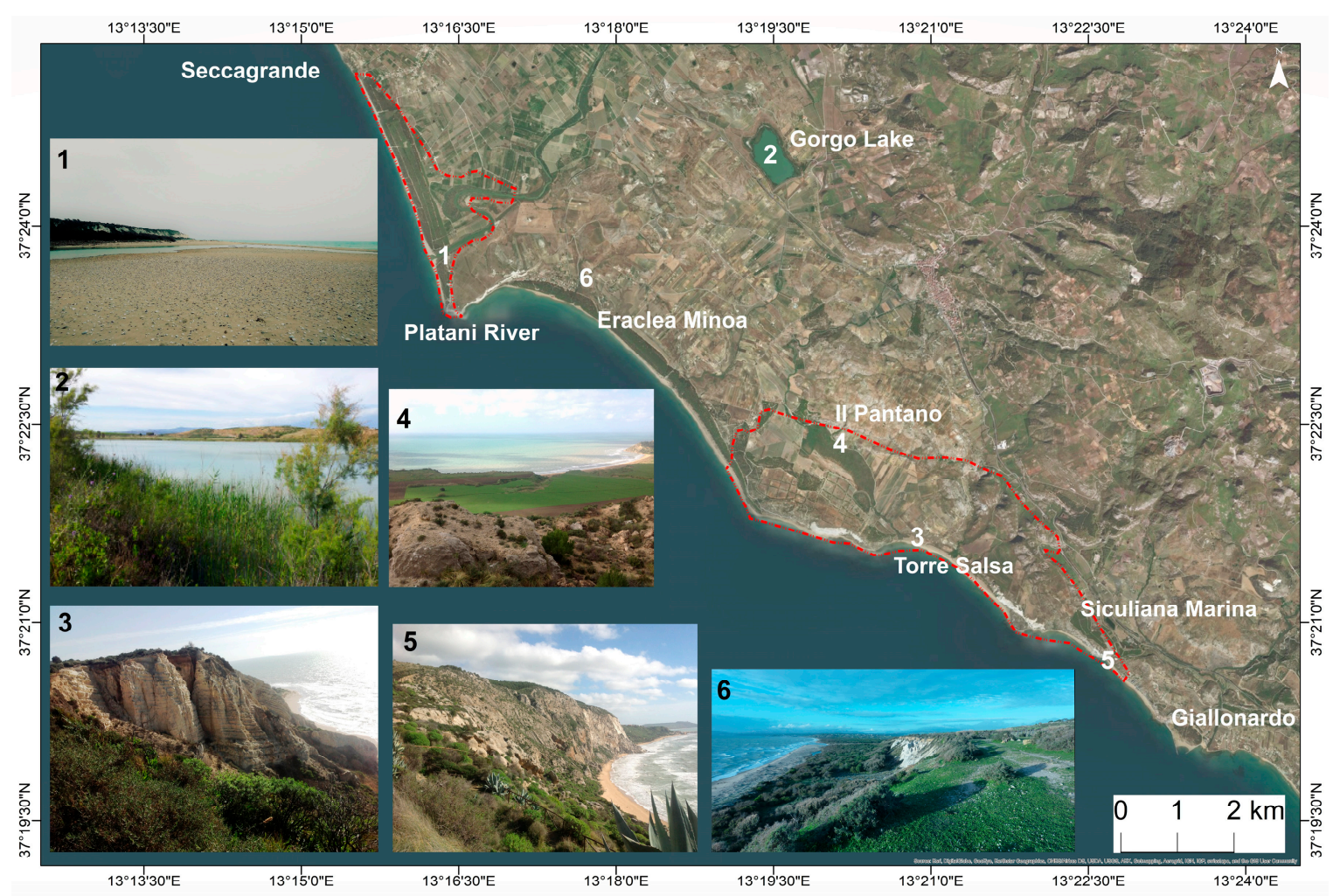

Figure 3. Outstanding geomorphological features of the Sicilian study area (GEOSIC): (1) sandy beach at the mouth of the River Platani; (2) Lake Gorgo hosted in a karst depression; (3) steep gypsum slopes and scrubland; (4) Il Pantano gypsum polje; (5) gypsum cliff affected by rock falls; (6) dune ridges and marine terraces. Red dashed-lines delimit respectively River Platani reserve in the north and Torre Salsa reserve in the southeast.

The coastal sector shows a series of white coloured promontories mainly made of "trubi" (i.e., soft, white, Globigerina-rich limestone) spaced out by large and beautiful sandy beaches, extensive dune ridges and coastal ponds. These cliffs are also characterised by the outcropping of gypsum and sandstones and are affected by numerous landslides, mainly rock falls and block slides.

The action of morphogenetic processes on the clayey slopes seems related principally to the slope angle. In fact, badland processes (also favoured by the alternation of dry summers and rainy autumns) affect the vegetation-free slopes with steeper gradients, whereas shallow landslides, rills and gullies often characterise the gentler hillsides.

Two types of coastal dune ridges can be observed in the area: stabilised dunes, with Mediterranean thermophilic pinewoods, and mobile dunes, with Ammophila arenaria (white dunes). The largest dune system is located near the River Platani mouth.

Karst processes affect the gypsum that shows a great variety of surface landforms, such as polje and a lot of microforms like karren, gypsum bubbles in micro- and macro-crystalline gypsum. In the central part of the area there is a polje depression named Il Pantano consisting of a $2.5 \mathrm{~km}$ long and $900 \mathrm{~m}$ wide flat and nearly horizontal floor, bounded by steep slopes and formed in a tectonic depression linked to a NW-SE thrust. 


\section{Materials and Methods}

It is clear that any action aimed at protecting or promoting geoheritage should include the selection and ranking of its most valuable elements. In the past 15 years an outstanding effort has been devoted to the development of methods for the qualitative and quantitative assessment of geosites or geomorphosites in various contexts (e.g., within Environmental Impact Assessment and territorial planning: [44-48]; inventories of natural heritage sites: [49-53]; tourist promotion: [54,55]; management of nature parks: [56-59]).

Based on published literature as well as our own field experience and outputs achieved in previous investigations on geoheritage assessment carried out in various morpho-climatic contexts, a methodology was applied for the selection and assessment of elements of geological interest. This includes: (i) selection of geosites based on three criteria: morphogenesis, spatial distribution and temporal scale [53,57]; (ii) quantitative assessment of geosites; (iii) ranking of geosites based on their management and tourism ratings. Prior to this, an in-depth geological and geomorphological investigation of the selected areas in Malta and Sicily was performed, also aiming to outline the above mentioned geological l.s. similarities and differences. This approach benefits from experience acquired by the authors in previous studies carried out in the Maltese Archipelago $[16,34,60]$ for the selection phase, which required an original adaptation to the Mediterranean morpho-climatic context of former criteria for geosites' quantitative assessment. Finally, in order to rank geosites in terms of management and tourism promotion, the method proposed by Feullet and Sourp [57] was applied.

\subsection{Selection of Geosites}

The first step of the procedure was the selection of sites of geological and geomorphological interest in both areas of Malta and Sicily. Following the approach proposed for geomorphosites selection by Reynard et al. [50], the following three criteria have been considered:

- The first criterion deals with the genesis of landforms [57]. It considers landforms that are representative of the main geomorphological processes (active and inactive) that have acted through time in the study areas.

- The second criterion concerns the spatial scale and refers to the spatial distribution of landforms. We have selected unique or rare landforms as well as more common and abundant ones. The selection based on this criterion aims to reflect the geo(morpho)diversity of the study areas [53].

- The third criterion concerns the temporal scale. The study areas are varied and dynamic, and combine active processes and landforms and inherited landforms which could be reactivated by currently active processes. In particular, active geosites (cf. [61,62]) have a high educational value because they allow us to: (i) understand and visualise geomorphological processes in action; (ii) envisage landscape evolution; (iii) highlight their relationship with present societies and their future development $[63,64]$. Inherited geosites (i.e., passive geosites $[61,63]$, which take us back to the past and have a particular heritage value as records and symbols of Earth's history and evolution. The selection based on this criterion aims to be representative of the study areas' history and of their geomorphological evolution in time [53].

\subsection{Quantitative Assessment of Geosites}

Numerous methods for the quantitative assessment of geoheritage are described in literature ([52,65] and references therein). The assessment procedure here applied was developed based on previous works $[50,53,57]$ and benefited from the outputs of its application in the Isand of Gozo [60]. In particular, considering that the study areas are mainly rural, more emphasis was given to ecological and aesthetic values than to cultural ones, which where anyhow taken into account. The following values and corresponding criteria were used (Table 1): (i) scientific value; (ii) additional values and (iii) use value. The scientific value is directly related to scientific aspects of the sites and its assessment is based on four criteria scored on a scale from 0 to 1 . The additional value highlights possible links 
between geological features and other natural and cultural aspects and is made up of three independent sub-values: ecological, aesthetic and cultural l.s. The use value concerns the possible fruition of geosites by society. The economic value was considered as part of the use value because the criteria set for the assessment of the latter (accessibility, visibility, services and importance for education) imply economic and recreational needs.

The total value of a geosite results from the sum of the scores of all criteria, with 10 as the highest score attainable.

Table 1. Values, corresponding criteria and numerical range of criteria used for the quantitative assessment of geosites.

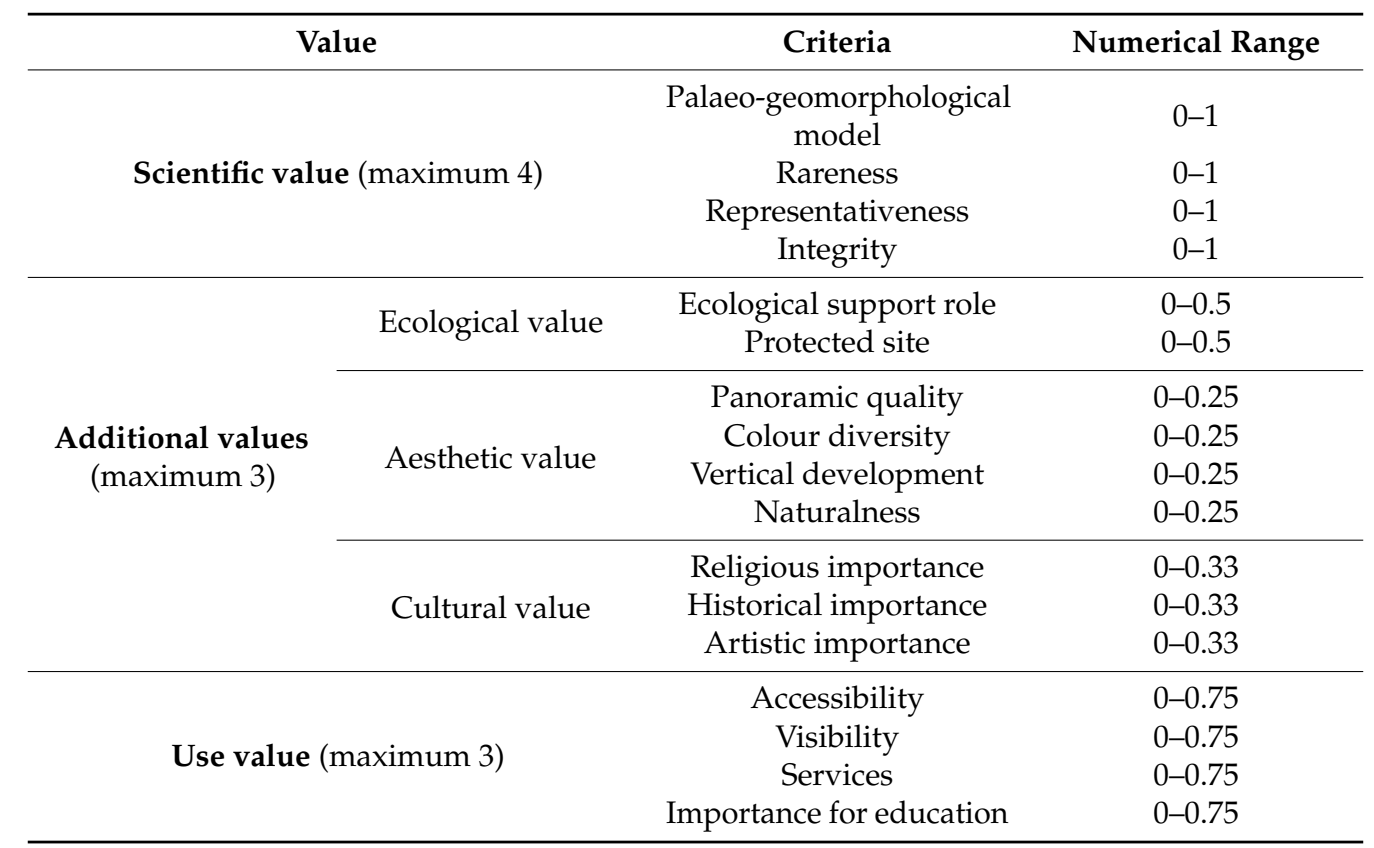

\subsection{Ranking of Geosites}

In this research, we assessed the geosites selected not only on a quantitative basis but we also established a ranking criterion, which could allow the definition of the most significant geosites in terms of management and tourism promotion. The methodology, elaborated by Feuillet and Sourp [57], was applied to the list of geosites, and the management rating (MR) and the tourism rating (TR) were calculated. These two ratings are defined as:

(1) $\quad \mathrm{MR}=\mathrm{SV}+(\mathrm{AV}+\mathrm{UV}) / 2$

(2) $\quad \mathrm{TR}=(\mathrm{AV}+\mathrm{UV})+(\mathrm{SV} / 2)$

According to Feuillet and Sourp [57], the MR, which mainly depends on scientific values, is functional to supporting site management decision concerning prioritization of measures for protection and conservation actions. On the other hand, the TR, which mainly reflects additional and use values, highlights sites more suitable for geotourism and education.

\section{Results}

\subsection{Selection of Geosites}

The selection phase, based on the three criteria previously explained, led to the establishment of a list of geosites counting 42 sites, 20 in Malta (Figure 4) and 22 in Sicily (Figure 5). This list is representative of the principal geomorphological contexts and of the various stages of regional morphogenesis of the study areas (Figure 6). 


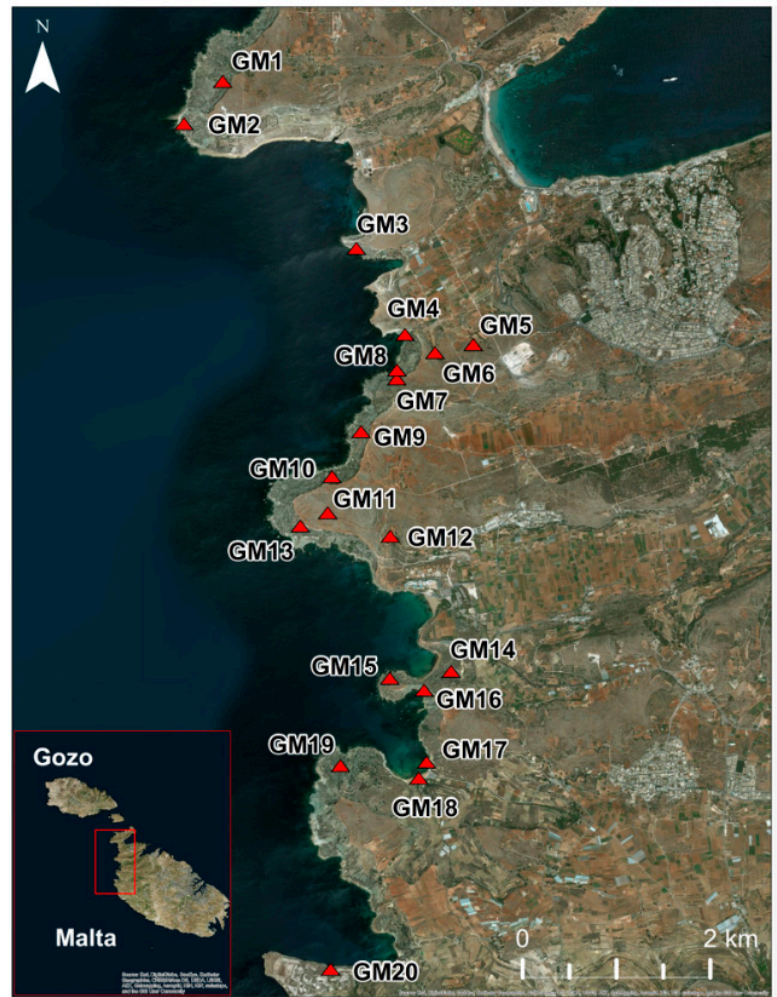

\begin{tabular}{|l|ll} 
Id & Process & \multicolumn{1}{c}{ Landform } \\
GM1 & Gr & Rock spreading \\
GM2 & Cst & Shore platform \\
GM3 & Gr & Rock spreading \\
GM4 & Flv_Er & Badlands \\
\hline GM5 & Krs & Sinkhole \\
\hline GM6 & Flv_Er & Dry valley \\
GM7 & Krs & Sinkhole \\
GM8 & Flv_Er & Badlands \\
GM9 & Gr & Rock spreading \\
\hline GM10 & Gr & Rock spreading \\
GM11 & Krs & Karst landform \\
\hline GM12 & Flv_Er & Dry valley \\
GM13 & Gr & Rock spreading \\
GM14 & Flv_Er & Badlands \\
GM15 & Gr & Rock spreading \\
GM16 & Flv_Er & Badlands \\
GM17 & Cst & Shore platform \\
GM18 & Cst & Sandy beach \\
\hline GM19 & Gr & Rock spreading \\
GM20 & Tct & Fault \\
\hline
\end{tabular}

Figure 4. Geosites map of Malta study area (GEOMAL) with the indication of the identification code, the predominant landforms (Gr: gravity-induced landforms, Cst: coastal landforms, Flv_Er: fluvial and water erosion landforms; Krs: karst landforms, Tct: tectonic landforms).

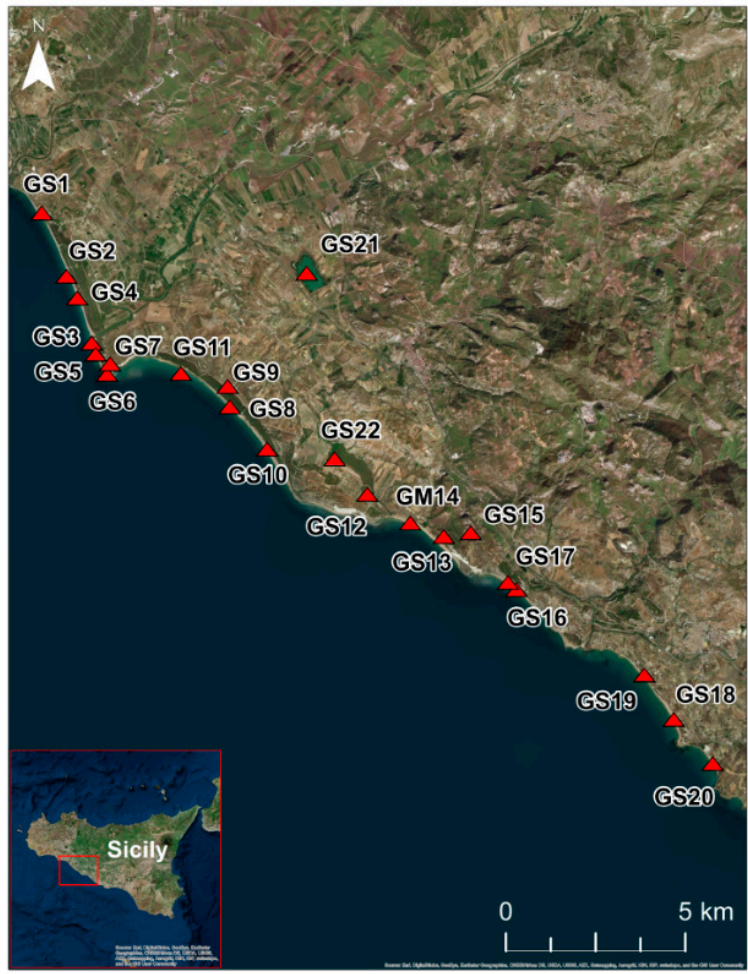

\begin{tabular}{rll} 
Id & Process & \multicolumn{1}{c}{ Landform } \\
GS1 & Gr & Rock falls \\
GS2 & Cst & Sandy beach \\
GS3 & Cst & Estuary \\
GS4 & Cst & Dune ridges \\
GS5 & Cst & Coastal pond \\
GS6 & Cst & Cliff \\
GS7 & Flv_Er & Terrace \\
GS8 & Flv_Er & Badlands \\
GS9 & Cst & Dune ridges \\
GS10 & Cst & Dune ridges \\
GS11 & Cst & Sandy beach \\
GS12 & Flv_Er & Gully \\
GS13 & Flv_Er & Gully \\
GS14 & Cst & Dune ridges \\
GS15 & Krs & Karren \\
GS16 & Gr & Rock slide \\
GS17 & Gr & Rock slide \\
GS18 & Flv_Er & Badlands \\
GS19 & Gr & Rock slide \\
GS20 & Flv_Er & Badlands \\
GS21 & Krs & Karst lake \\
GS22 & Krs & Polje
\end{tabular}

Figure 5. Geosites map of Sicily study area (GEOSIC) with the indication of the identification code, the predominant landforms (Gr: gravity-induced landforms, Cst: coastal landforms, Flv_Er: fluvial and water erosion landforms; Krs: karst landforms, Tct: tectonic landforms). 


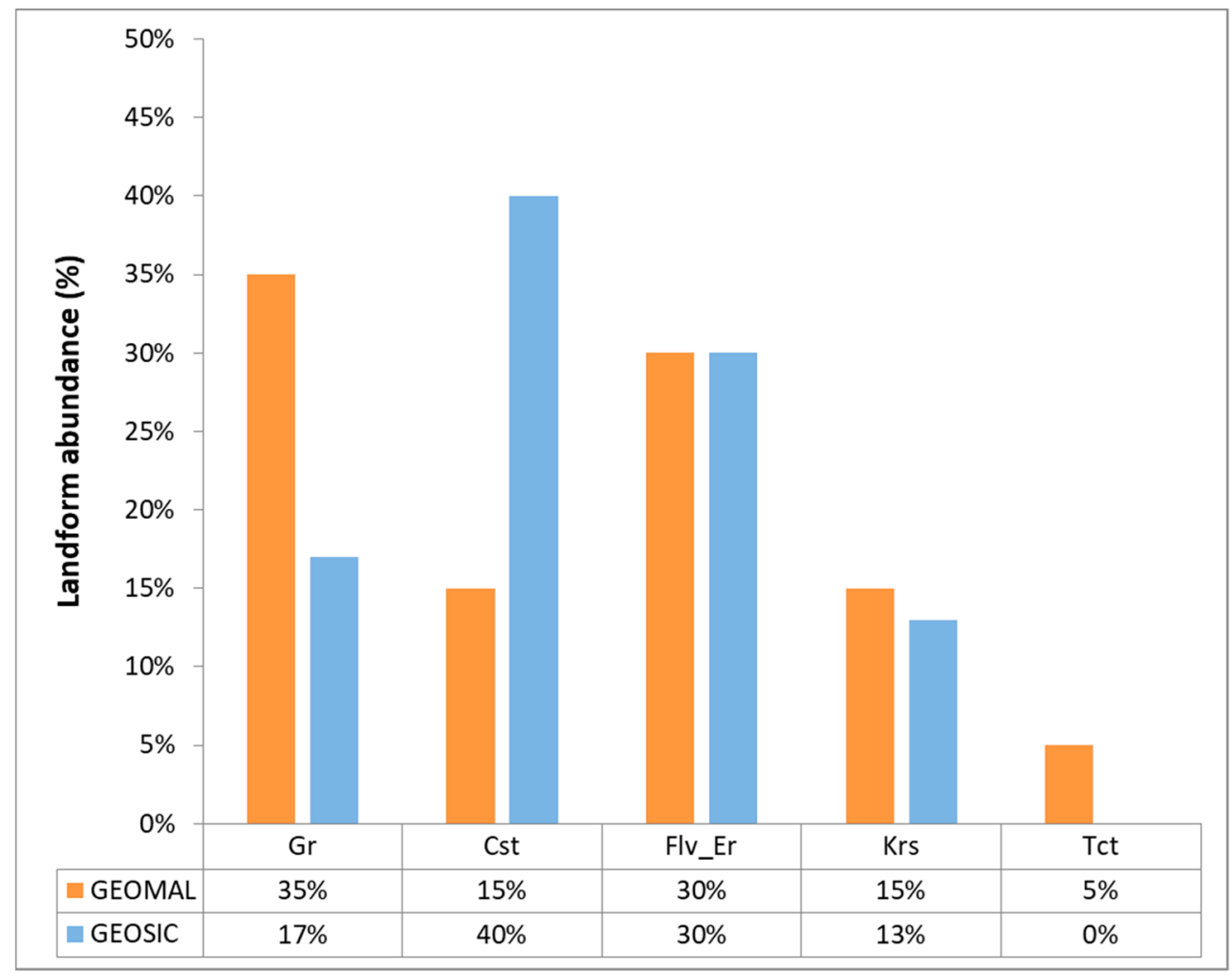

Figure 6. Morphogenetic characterisation and distribution of geosites in Malta (GEOMAL) and Sicily (GEOSIC) study areas (Gr: gravity-induced landforms, Cst: coastal landforms, Flv_Er: fluvial and water erosion landforms; Krs: karst landforms, Tct: tectonic landforms).

In GEOMAL the most common selected features are gravity-induced landforms (30\%), which reflect the main active modelling process of this sector of the island at present. Fluvial and coastal geosites are equally represented ( $25 \%$ each). Among landforms created by running water, both active (badlands) and inherited features (dry valleys), relict forms of past pluvial conditions were selected. Only one structural feature was selected in the study area since it is the most attractive and easily recognisable by tourists.

In GEOSIC the more abundant selected landforms are mainly related to coastal (39\%) and fluvial (30\%) erosional processes whereas gravity-induced landforms (17\%) are less abundant. Karst landforms are rare and inherited, since they witness a past stage of regional morphogenesis (13\%).

This research phase has provided original datasets for the inventory of geoheritage and geosites in the study areas. In fact, the Island of Malta still lacks an official inventory of sites of geological interest, whilst in Sicily an inventory at regional scale is still in progress, comprising at present only the GS22 site that is a large karst depression (Il Pantano, Torre Salsa Reserve).

\subsection{Quantitative Assessment and Ranking of Geosites}

All the 42 geosites were assessed and the results are summarized in Tables 2 and 3. The outline of the scores enables comparisons of value distribution. Figures 7 and 8, created by GIS processing, display the spatial distribution of the geosites, in Malta and Sicily respectively, according to their management score and tourism score. In Malta, the area extending from Il-Prajjet to Rdum Majjiesa and that surrounding Ghajn Tuffieha appear the most valuable, showing a high concentration of sites with high scores in both management and tourism rating. This can be explained by taking into account a cause-effect relationship. In fact, these areas correspond respectively to the Il-Majjistral Nature and History Park and to a coastal stretch characterised by tourism facilities. Similarly, in Sicily the most valuable sites are concentrated in the surrounding of the River Platani and Torre Salsa reserves. 
As regards GEOMAL, among the 20 geosites selected, three main clusters of increasing management and tourism ranking sites can be distinguished (Figure 9).

Table 2. General numerical assessment of the 20 sites of the Malta study area (GEOMAL). Legend: SV, scientific value; $\mathrm{AV}$, additional value; $\mathrm{UV}$, use value; $\mathrm{MR}$, management rating; $\mathrm{TR}$, tourism rating.

\begin{tabular}{ccccccccc}
\hline $\begin{array}{c}\text { Malta } \\
\text { Geosites }\end{array}$ & SV & AV & UV & Total & MR & TR & $\begin{array}{c}\text { Management } \\
\text { Ranking }\end{array}$ & $\begin{array}{c}\text { Tourism } \\
\text { Ranking }\end{array}$ \\
\hline GM1 & 3.25 & 0.75 & 1.25 & 5.25 & 4.25 & 3.63 & 13 & 17 \\
GM2 & 3.75 & 0.75 & 1.25 & 5.75 & 4.75 & 3.88 & 7 & 13 \\
GM3 & 3.25 & 1.58 & 3 & 7.83 & 5.54 & 6.21 & 3 & 2 \\
GM4 & 3.5 & 1.25 & 1 & 5.75 & 4.63 & 4.00 & 11 & 12 \\
GM5 & 2.5 & 0.25 & 0.75 & 3.5 & 3.00 & 2.25 & 18 & 19 \\
GM6 & 2 & 1.08 & 0.5 & 3.58 & 2.79 & 2.58 & 19 & 18 \\
GM7 & 2.5 & 1.5 & 1.5 & 5.5 & 4.00 & 4.25 & 16 & 10 \\
GM8 & 3.75 & 1.5 & 2 & 7.25 & 5.50 & 5.38 & 4 & 5 \\
GM9 & 3.25 & 1.58 & 1.25 & 6.08 & 4.67 & 4.46 & 8 & 7 \\
GM10 & 3.25 & 1.58 & 1.25 & 6.08 & 4.67 & 4.46 & 9 & 16 \\
GM11 & 2.5 & 1.08 & 1.25 & 4.83 & 3.67 & 3.58 & 17 & 20 \\
GM12 & 1.75 & 0.75 & 0.5 & 3 & 2.38 & 2.13 & 20 & 4 \\
GM13 & 3.25 & 1.33 & 2.5 & 7.08 & 5.17 & 5.46 & 5 & 11 \\
GM14 & 2.75 & 1 & 1.75 & 5.5 & 4.13 & 4.13 & 15 & 3 \\
GM15 & 3.5 & 2.33 & 2 & 7.83 & 5.67 & 6.08 & 2 & 1 \\
GM16 & 3.5 & 2.33 & 2.75 & 8.58 & 6.04 & 6.83 & 1 & 14 \\
GM17 & 3.5 & 0.75 & 1.25 & 5.5 & 4.50 & 3.75 & 12 & 6 \\
GM18 & 3.25 & 1 & 1 & 5.25 & 4.25 & 3.63 & 14 & 9 \\
GM19 & 3 & 1.08 & 2.25 & 6.33 & 4.67 & 4.83 & 10 & 6 \\
GM20 & 3.75 & 1.33 & 1.25 & 6.33 & 5.04 & 4.46 & 6 & \\
\hline
\end{tabular}

Table 3. General numerical assessment of the 22 sites of the Sicily study area (GEOSIC). Legend: SV, scientific value; $\mathrm{AV}$, additional value; $\mathrm{UV}$, use value; $\mathrm{MR}$, management rating; $\mathrm{TR}$, tourism rating.

\begin{tabular}{|c|c|c|c|c|c|c|c|c|}
\hline $\begin{array}{c}\text { Sicily } \\
\text { Geosites }\end{array}$ & SV & AV & UV & Total & MR & TR & $\begin{array}{l}\text { Management } \\
\text { Ranking }\end{array}$ & $\begin{array}{l}\text { Tourism } \\
\text { Ranking }\end{array}$ \\
\hline GS1 & 2.25 & 0.5 & 1.25 & 4 & 3.13 & 2.88 & 21 & 21 \\
\hline GS2 & 2.75 & 1.75 & 2.00 & 6.5 & 4.63 & 5.13 & 11 & 8 \\
\hline GS3 & 3.75 & 2.08 & 2.00 & 7.83 & 5.79 & 5.96 & 4 & 3 \\
\hline GS4 & 2.25 & 1.75 & 1.30 & 5.3 & 3.78 & 4.18 & 5 & 16 \\
\hline GS5 & 4 & 1.75 & 2.00 & 7.75 & 5.88 & 5.75 & 3 & 4 \\
\hline GS6 & 4 & 2.66 & 2.00 & 8.66 & 6.33 & 6.66 & 2 & 1 \\
\hline GS7 & 3 & 1.91 & 2.25 & 7.16 & 5.08 & 5.66 & 9 & 5 \\
\hline GS8 & 2.75 & 1.75 & 1.00 & 5.5 & 4.13 & 4.13 & 14 & 18 \\
\hline GS9 & 2 & 1 & 2.50 & 5.5 & 3.75 & 4.50 & 19 & 13 \\
\hline GS10 & 2 & 1 & 2.50 & 5.5 & 3.75 & 4.50 & 20 & 14 \\
\hline GS11 & 2.25 & 1 & 2.75 & 6 & 4.13 & 4.88 & 15 & 11 \\
\hline GS12 & 3.5 & 1 & 2.25 & 6.75 & 5.13 & 5.00 & 8 & 9 \\
\hline GS13 & 3 & 1 & 2.25 & 6.25 & 4.63 & 4.75 & 12 & 15 \\
\hline GS14 & 2.75 & 1.5 & 1.30 & 5.55 & 4.15 & 4.18 & 13 & 17 \\
\hline GS15 & 3.75 & 1.83 & 1.25 & 6.83 & 5.29 & 4.96 & 7 & 10 \\
\hline GS16 & 3 & 1 & 2.75 & 6.75 & 4.88 & 5.25 & 10 & 7 \\
\hline GS17 & 2.25 & 1 & 2.75 & 6 & 4.13 & 4.88 & 16 & 12 \\
\hline GS18 & 3 & 1 & 1.00 & 5 & 4.00 & 3.50 & 17 & 19 \\
\hline GS19 & 1 & 1 & 0.75 & 2.75 & 1.88 & 2.25 & 22 & 22 \\
\hline GS20 & 3 & 1 & 1.00 & 5 & 4.00 & 3.50 & 18 & 20 \\
\hline GS21 & 4 & 1.25 & 2.25 & 7.5 & 5.75 & 5.50 & 6 & 6 \\
\hline GS22 & 4 & 2.08 & 2.25 & 8.33 & 6.17 & 6.33 & 1 & 2 \\
\hline
\end{tabular}



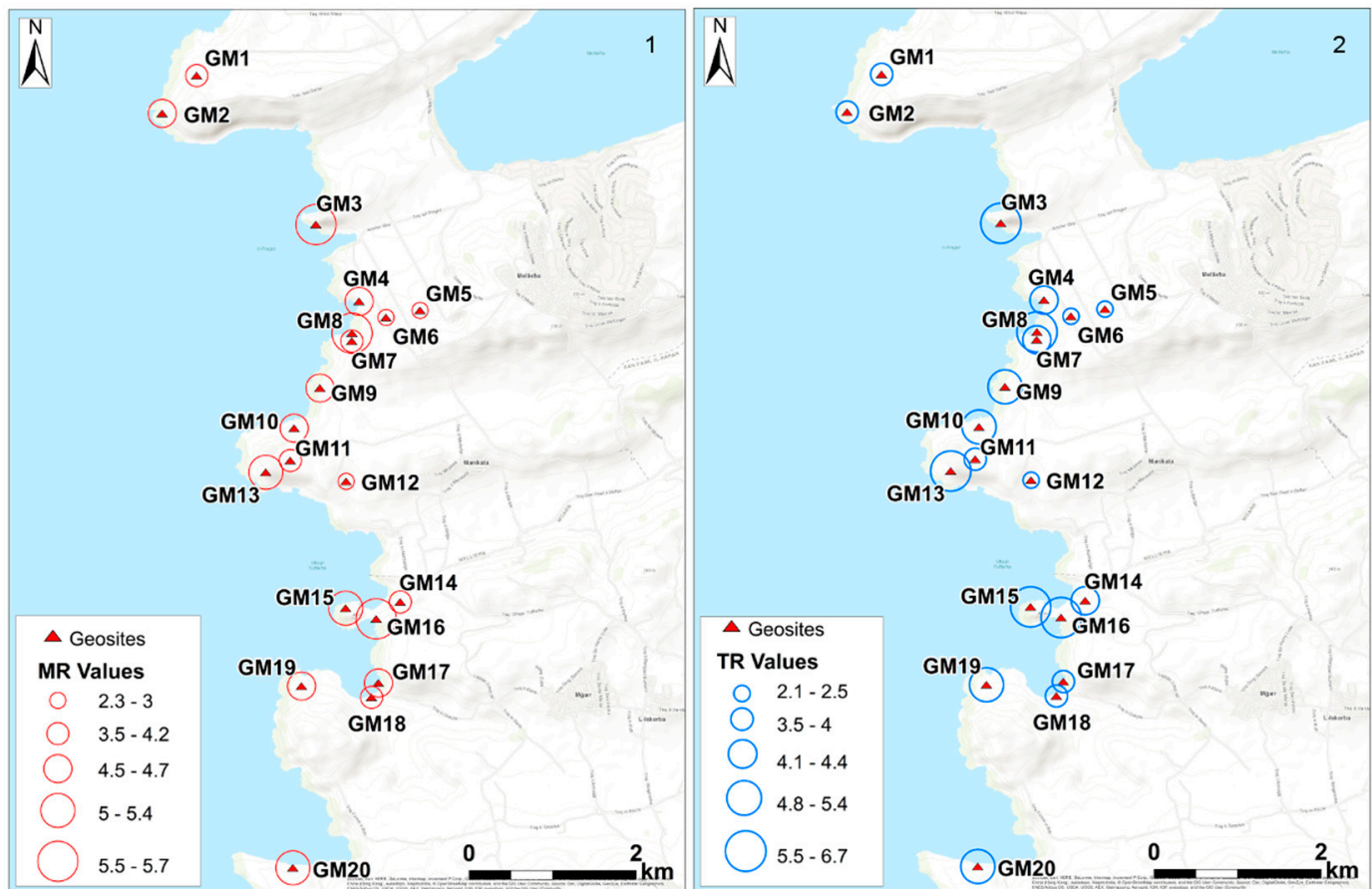

Figure 7. Geosite distribution according to management ranking (1) and tourism ranking (2) in Malta study area (GEOMAL).
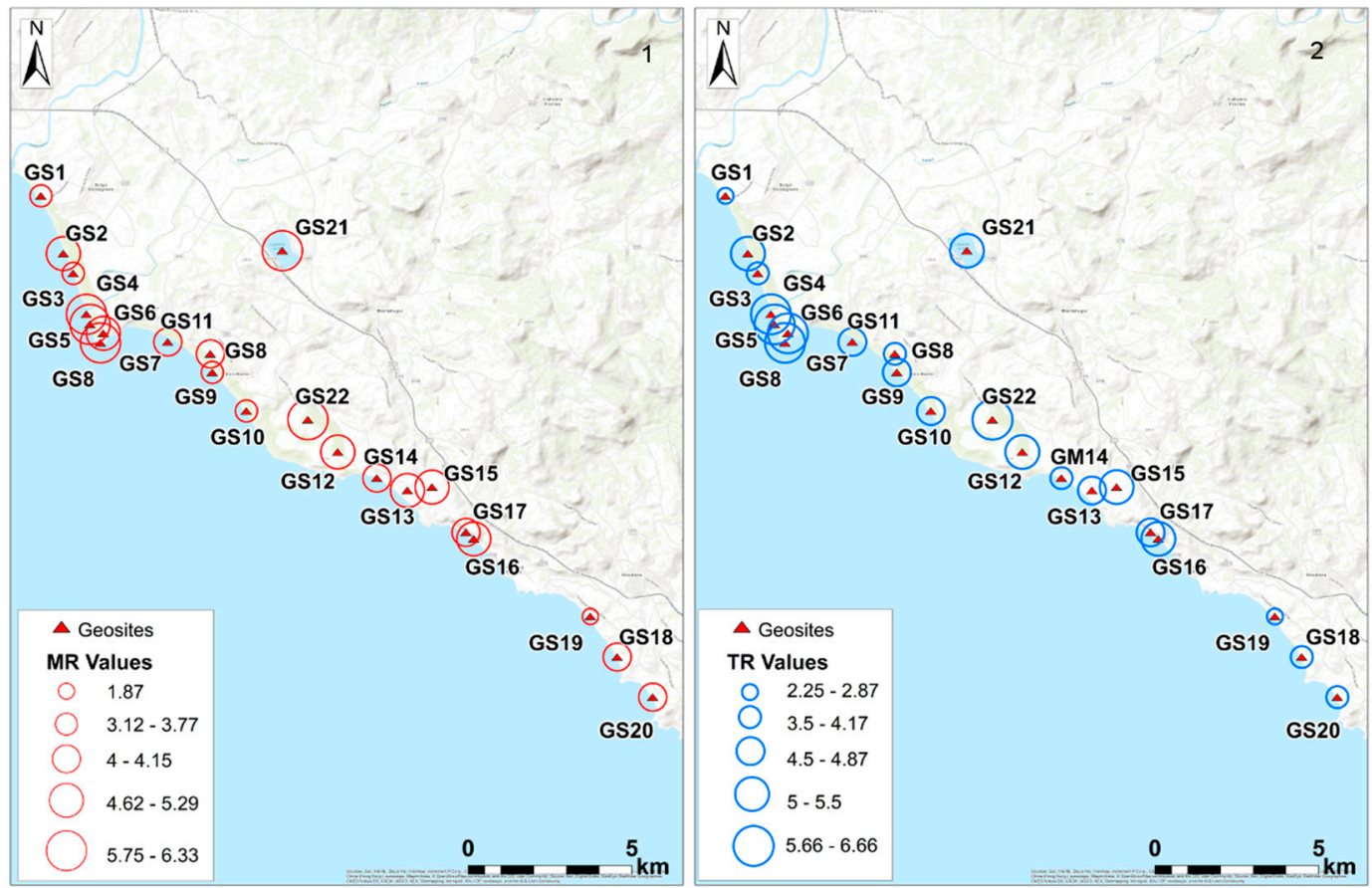

Figure 8. Geosite distribution according to management ranking (1) and tourism ranking (2) in Sicily study area (GEOSIC).

The first cluster contains $25 \%$ of the selected geosites, showing the highest scores in both management and tourism rating: GM16, GM3, GM15, GM13, GM8. These sites, which are related to the most significant landforms observable in the area, are already exploited as tourist sites, but not for their scientific significance and can be considered a priority for management and geotourism 
development. GM16 and GM15 are located in Ghajn Tuffieha Bay, one of the most popular tourist areas with high scenic value.

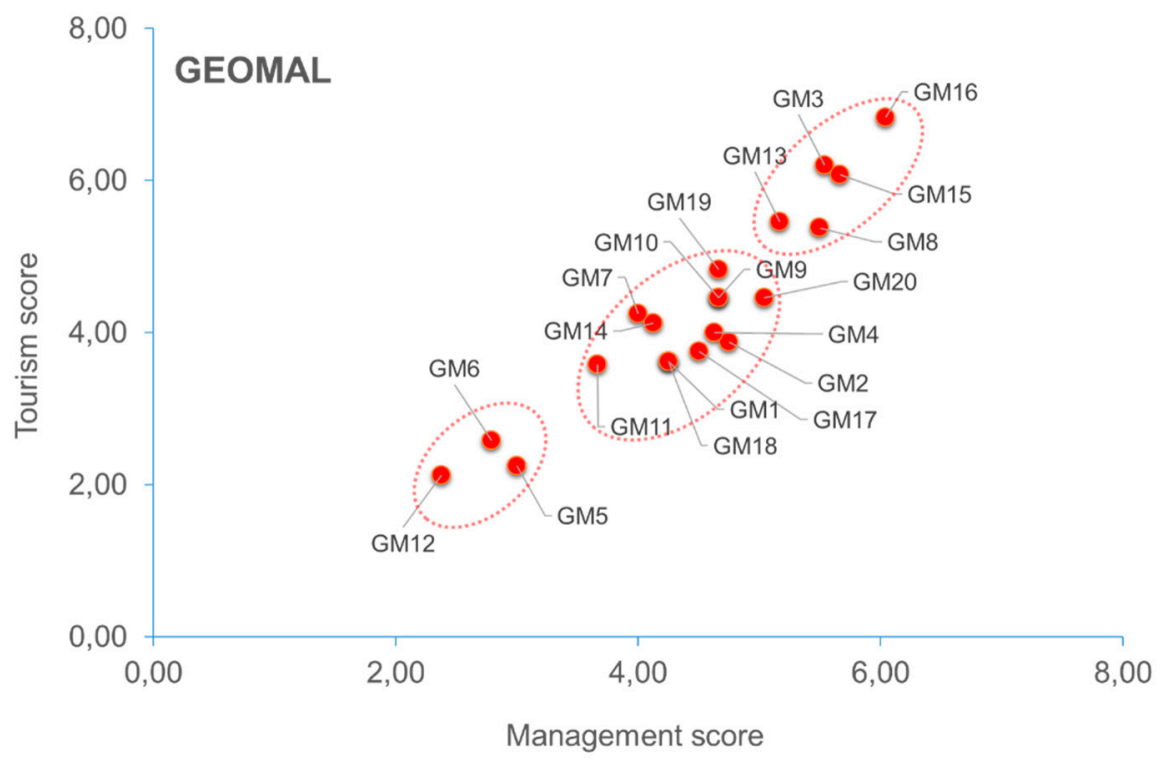

Figure 9. Clustering of the 20 geosites in the Malta study area.

The second cluster, which is the largest one, comprises $60 \%$ of the selected geosites and is characterised by medium management and tourism scores. The GM19 site (area affected by rock spreading) can be distinguished from other geosites of the same group because of its quite high tourism ranking, but with a medium management ranking. For this reason, the site can be included in the list of high priority sites in terms of tourism promotion.

A third cluster is composed of $15 \%$ of the selected geosites and is characterised by weak management and tourism scores: GM6, GM5 and GM12. In particular, two of them are valleys (GM5, GM12) carved within limestone bedrock. Nowadays they are dry and only host ephemeral streams during intense precipitation events. Since these sites are the result of fluvial processes that have acted in wetter conditions in the past, they have an average scientific value due to their representativeness. However, they show a very low score of additional and use values, since they are landforms with low aesthetic value located inland with scarce visibility and accessibility. GM5 is a sinkhole of about $75 \mathrm{~m}$ in diameter filled by a shallow layer of soil, mainly composed of sand, clay and terra rossa. This site, which is used for farming, shows the lowest score of additional and use values.

As regards GEOSIC, among the 22 selected sites, three clusters of increasing management and tourism ranking sites can be recognised by plotting the geosite ranking results (Figure 10).

The first cluster comprises $22 \%$ of the selected geosites and shows high values of TS and MS: GS6, GS22, GS3, GS5 and GS21. These sites are located in areas characterised by a significant natural and cultural heritage and high ecological value. The remarkable scientific value is due to the presence of particular (coastal and karst) landforms, typical of the central and southern part of Sicily. The River Platani mouth (GS3) and the nearby carbonate reliefs (GS6) are highly representative from the geomorphological viewpoint as well as the karst lake (GS21), the polije (GS22) and the coastal ponds (GS5). In particular, the ephemeral nature of the latter increases their representativeness.

The second cluster comprises $66 \%$ of the selected geosites and is characterised by medium management and tourism scores. The GS7 site can be distinguished from other geosites of the same group because of its quite high tourism ranking and for this reason it can be included in the list of high priority sites in terms of tourism promotion. This terrace, where the ancient ruins of Eraclea Minoa are the principal attraction, has a valuable potential for tourism not only in relation to the 
archaeological value, but also for its geomorphological significance in relation to the evolution of the coastal landscape and, in particular, to the retreat of the cliff.

The third cluster is composed of $9 \%$ of the selected geosites and is characterised by weak management and tourism scores: GS1 and GS19, rock falls and rock slides, respectively. Because of their low representativeness in terms of process intensity and landforms, these two sites have a low scientific value. In addition, their scarce visibility and accessibility are responsible for the very low score of additional and use values, even if they show an average aesthetic value of the landscape.

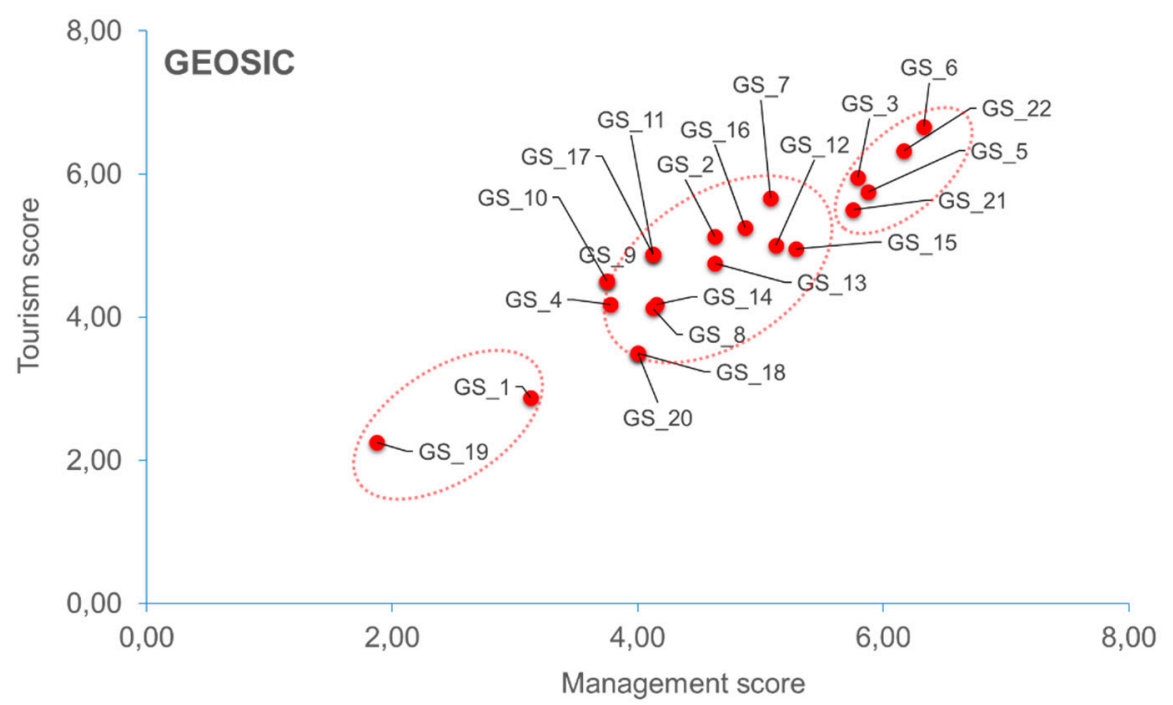

Figure 10. Clustering of the 22 geosites in the Sicily study area.

\section{Conclusions}

Malta and Sicily have shared a long-standing history from pre-historic times until a couple of centuries ago. They have a multi-millennial common history, witnessed by valuable archaeological heritage, outstanding pieces of architecture and a rich cultural similarity, including also language affinities. However, similarities between the Maltese Islands and Sicily reside also in their common geological history and in their palaeo-geographical and palaeo-environmental evolution during the past million years. Common stratigraphic sequences, similar outcropping rocks and findings of remarkable vertebrate fossils in both areas testify this. After the Second World War, which had severe consequences both in Malta and Sicily, the common belonging to the European Union and re-established enthusiasm for common actions has progressively linked Malta and Sicily, which have rediscovered their common roots. In this perspective, the identification of geosites in these two areas, which display not only evidence of commonality but also of diversity, make up a key element for integrated actions and policies. By identifying and assessing geosites in this representative sector of the Mediterranean, it is possible to create a virtual bridge between two territories that are very close to each other, though separated by a physical border such as the sea. A bridge like this would recall the palaeo-geographic conditions and retrace the geological and anthropological history of the stretches of coast selected in Sicily and Malta, which in the geological past were physically united and protagonists of the cultural history of the central portion of the Mediterranean Sea.

Geosites selected from two coastal areas have been recognized and assessed within the EC-funded Project "Ecological Malta-Sicily Cross-border Networks" (RE.MA.SI) that was recently completed. The Project and the research here illustrated aimed at the creation of a geosite network between Sicily and the Maltese archipelago, by sharing scientific knowledge and experience in environmental management, which can certainly favour an increase of nature and cultural tourism thanks to a deeper understanding of the geological and geomorphological contexts, with expected positive feedbacks in socioeconomic terms. The geosites here illustrated outline similarities and differences in the geological 
and environmental evolution of two coastal stretches facing the same sea: they provide elements for the building up of an "Earth memory" which is a key for interpreting future tendencies based on the understanding of recent geological history. The above mentioned geosite network is meant to appraise the common geological history of Malta and Sicily by virtually re-establishing the geological bridge which physically merged Italy and Malta during the upper Pleistocene, thus creating the ground for diversified but common conservation actions and policies.

This paper is the result of the first in-depth research on geoheritage in the investigated areas of Malta and Sicily and provides the necessary ground for interested parties to take actions for the protection and conservation of regions of exceptional geological interest. The methodological approach here applied is an effective tool for territorial analysis, which can be crucial for land management purposes. The datasets, collected and organised in a hierarchy, can be used to target priority geosites in terms of both management and tourism issues. For geotourism purposes, the geosites showing high and average tourism rates could be targeted for cross-border strategies of management and promotion, also exportable to other similar contexts.

In both study areas, top positions in ranking are occupied by geosites which are already exploited as tourist sites, although apparently not because of their geological significance. However, as highlighted by various authors [66-68] very often the geosite attractiveness is strictly related to their scenic value. By contrast, in the study area the lowest positions in our ranking are occupied by geosites with a significant scientific value but poorly accessible or lacking additional values.

A further step of the research should consider tourists' and visitors' opinions and potential preferences to assess the attractiveness of geosites from a tourist point of view. In particular, in order to compare and validate the results here obtained, the geosites selected and assessed in the present could be further evaluated based on methodologies recently developed, in which the attractiveness of sites is assessed from the perspective of different category of visitors and tourists [68,69].

Author Contributions: Conceptualisation, C.C., P.C., V.A. and M.S.; Data curation, C.C.; Funding acquisition, V.A.; Investigation, C.C. and P.C.; Methodology, P.C.; Project administration, V.A.; Supervision, M.S.; Writing-original draft, C.C. and P.C.; Writing-review \& editing, P.C. and M.S.

Funding: PO Italia-Malta 2007-13, RE.MA.SI, funded this research. Project grant number Cod A1.2.1-16.

Acknowledgments: The authors are grateful to the three anonymous reviewers for their useful suggestions as well as to Giovanni Tosatti for the critical reading of the manuscript and Andrea Mary Lord for reviewing the English text.

Conflicts of Interest: The authors declare no conflict of interest.

\section{References}

1. Hose, T.A. Selling the story of Britain's stone. Environ. Interpret. 1995, 10, 16-17.

2. Hose, T.A. European geotourism-geological interpretation and geoconservation promotion for tourists. In Geological Heritage: Its Conservation and Management; Barretino, D., Wimbledon, W.P., Gallego, E., Eds.; Instituto Tecnologico Geominero de España: Madrid, Spain, 2000; pp. 127-146.

3. National Geographic Society. Available online: http://www.nationalgeographic.com/maps/geotourism/ about (accessed on 29 May 2017).

4. Joyce, B. Geotourism, Geosites and Geoparks: Working together in Australia. Aust. Geol. 2007, 144, $26-29$.

5. Dowling, R.K.; Newsome, D. Geotourism: Sustainability, Impacts and Management; Elsevier/Heineman Publishers: Oxford, UK, 2006.

6. Dowling, R.K.; Newsome, D. (Eds.) Global Geotourism Perspectives; Goodfellow Publishers: Oxford, UK, 2010.

7. Ollier, C. Problems of geotourism and geodiversity. Quaest. Geogr. 2012, 31, 57-61.

8. Mansur, K.L.; Soares Da Silva, A. Society's response: Assessment of the performance of the "Caminhos Geológicos" ("Geological Paths") Project, State of Rio de Janeiro, Brazil. Geoheritage 2010, 3, 27-39. [CrossRef]

9. Garavaglia, V.; Pelfini, M. Glacial geomorphosites and related landforms: A proposal for a dendrogeomorphological approach and educational trails. Geoheritage 2011, 3, 15-25. [CrossRef] 
10. Miccadei, E.; Piacentini, T.; Esposito, G. Geomorphosites and geotourism in the Parks of the Abruzzo Region (Central Italy). Geoheritage 2011, 3, 233-251. [CrossRef]

11. Cardozo Moreira, J. Interpretative panels about the geological heritage-A case study at the Iguassu Falls National Park (Brazil). Geoheritage 2012, 4, 127-137. [CrossRef]

12. Wrede, V.; Mügge-Bartolovicv, V. GeoRoute Ruhr-A network of geotrails in the Ruhr Area National GeoPark, Germany. Geoheritage 2012, 4, 109-114. [CrossRef]

13. Enniouar, A.; Lagnaoui, A.; Adnane, H. A Middle Jurassic sauropod tracksite in the Argana Basin, Western High Atlas, Morocco: An example of paleoichnological heritage for sustainable geotourism. Proc. Geol. Assoc. 2014, 125, 114-119. [CrossRef]

14. Gordon, J.E. Geoheritage, Geotourism and the Cultural Landscape: Enhancing the Visitor Experience and Promoting Geoconservation. Geosciences 2018, 8, 136. [CrossRef]

15. Soldati, M.; Buhagiar, S.; Coratza, P.; Magri, O.; Pasuto, A.; Schembri, J.A. Integration of geomorphology and cultural heritage: A key issue for present and future times. Geogr. Fis. Dinam. Quat. 2008, 31, 95-96.

16. Coratza, P.; Gauci, R.; Schembri, J.; Soldati, M.; Tonelli, C. Bridging Natural and Cultural Values of Sites with Outstanding Scenery: Evidence from Gozo, Maltese Islands. Geoheritage 2016, 8, 91-103. [CrossRef]

17. Holloway, R. The Archaeology of Ancient Sicily; Routledge: London, UK, 1991.

18. Bonanno, A. Malta, Phoenician, Punic and Roman; Midsea Books: Santa Venera, Malta, 2005.

19. Bonanno, A. The Rise of a Maritime Strategic Island: Malta under the Phoenicians \& the Romans. In Maritime History of Malta; The first Millennia; Cini, C., Borg, J., Eds.; Salesians of Don Bosco and Heritage Malta: Valletta, Malta, 2011; pp. 37-71.

20. Cini, C.; Borg, J. (Eds.) The Maritime History of Malta; The first Millennia; Salesians of Don Bosco and Heritage Malta: Valletta, Malta, 2011.

21. Dalli, C. Malta the Medieval Milennium; Midsea Books: Santa Venera, Malta, 2006.

22. Brandhoff, R.E. Malta and Sicily. Island identity in the Mediterranean; the 700 BC turning point. In Kaleidoscope of Maritime Perspectives; Essay on the archeology, art history and landscape history of the maritime word view; Raemaekers, D.C.M., Ed.; University of Groningen/Groningen Institute of Archaeology and Barkhuis Publishing: Gronigen, The Netherlands, 2013.

23. Cassar, C. A Concise History of Malta; Mireva Publications: Msida, Malta, 2000.

24. Djamali, M.; Gambin, B.; Marriner, N.; Andrieu-Ponel, V.; Gambin, T.; Gandouin, E.; Lanfranco, S.; Medail, F.; Pavon, D.; Ponel, P.; et al. Vegetation dynamics during the early to mid-Holocene transition in NW Malta, human impact versus climatic forcing. Veg. Hist. Archaeobot. 2013, 22, 367-380. [CrossRef]

25. Furlani, S.; Antonioli, F.; Biolchi, S.; Gambin, T.; Gauci, R.; Lo Presti, V.; Anzidei, M.; Devoto, S.; Palombo, M.; Sulli, A. Holocene sea level change in Malta. Quat. Int. 2013, 288, 146-157. [CrossRef]

26. Lambeck, K.; Antonioli, F.; Anzidei, M.; Ferranti, L.; Leoni, G.; Scicchitano, G.; Silenzi, S. Sea level change along the Italian coast during the Holocene and projections for the future. Quat. Int. 2011, 232, 250-257. [CrossRef]

27. Foglini, F.; Prampolini, M.; Micallef, A.; Angeletti, L.; Vandelli, V.; Deidun, A.; Soldati, M.; Taviani, M. Late Quaternary coastal landscape morphology and evolution of the Maltese Islands (Mediterranean Sea) reconstructed from high-resolution seafloor data. In Geology and Archaeology: Submerged Landscapes of the Continental Shelf; Harff, J., Bailey, G., Lüth, F., Eds.; Geological Society Special Publication: London, UK, 2016; Volume 411, pp. 77-95.

28. Agnesi, V.; Di Patti, C.; Truden, B. Giants of Sicily: From myth to science. In Myth and Geology; Special Publications; Piccardi, L., Masse, W.B., Eds.; Geological Society: London, UK, 2007; Volume 273, pp. 263-270.

29. Agnesi, V. Sicily in the last one million years. Bocconea 2004, 17, 23-32.

30. Catalano, R.; Di Stefano, P.; Sulli, A.; Vitale, F.P. Paleogeography and structure of the central Mediterranean: Sicily and its offshore area. Tectonophysics 1996, 260, 291-323. [CrossRef]

31. Prampolini, M.; Foglini, F.; Biolchi, S.; Devoto, S.; Angelini, S.; Soldati, M. Geomorphological mapping of terrestrial and marine areas, northern Malta and Comino (central Mediterranean Sea). J. Maps 2017, 13, 457-469. [CrossRef]

32. Alexander, D. A review of the physical geography of Malta and its significance for tectonic geomorphology. Quat. Sci. Rev. 1988, 7, 41-53. [CrossRef] 
33. Devoto, S.; Biolchi, S.; Bruschi, V.M.; Furlani, S.; Mantovani, M.; Piacentini, D.; Pasuto, A.; Soldati, M. Geomorphological map of the NW Coast of the Island of Malta (Mediterranean Sea). J. Maps 2012, 8, $33-40$. [CrossRef]

34. Coratza, P.; Bruschi, V.; Piacentini, D.; Saliba, D.; Soldati, M. Recognition and assessment of Geomorphosites in Malta at the Il-Majjistral Natural and History Park. Geoheritage 2011, 3, 175-185. [CrossRef]

35. Oil Exploration Directorate. Geological Map of the Maltese Islands; Office of the Prime Minister: Valletta, Malta, 1993.

36. Pedley, M.; Clarke, M.H.; Galea, P. Limestone Isles in a Crystal Sea, the Geology of the Maltese Islands; Publishers Enterprises Group: San Gwann, Malta, 2002.

37. Baldassini, N.; Di Stefano, A. Stratigraphic features of the Maltese Archipelago: A synthesis. Nat. Hazards 2017, 86 (Suppl. 2), 203-231. [CrossRef]

38. Soldati, M.; Barrows, T.T.; Prampolini, M.; Fifield, K.L. Cosmogenic exposure dating constraints for coastal landslide evolution on the Island of Malta (Mediterranean Sea). J. Coast. Conserv. 2017, 1-14. [CrossRef]

39. Magri, O.; Mantovani, M.; Pasuto, A.; Soldati, M. Geomorphological investigation and monitoring of lateral spreading phenomena along the north-west coast of Malta. Geogr. Fis. Dinam. Quat. 2008, 31, 171-180.

40. Mantovani, M.; Devoto, S.; Forte, E.; Mocnik, A.; Pasuto, A.; Piacentini, D.; Soldati, M. A multidisciplinary approach for rock spreading and block sliding investigation in the north-western coast of Malta. Landslides 2012. [CrossRef]

41. Said, G.; Schembri, J. Malta. In Encyclopaedia of the World's Coastal Landforms; Bird, E., Ed.; Springer: Dordrecht, The Netherlands, 2010; pp. 751-759.

42. Cyffka, B.; Bock, M. Degradation of field terraces in the Maltese Islands-Reasons, processes and effects. Geogr. Fis. Dinam. Quat. 2008, 31, 119-128.

43. Di Maggio, C.; Madonia, G.; Vattano, M.; Agnesi, V.; Monteleone, S. Geomorphological evolution of Western Sicily, Italy. Geol. Carpath. 2017, 68, 80-93. [CrossRef]

44. Barba, F.J.; Remondo, J.; Rivas, V. Propuesta de un procedimiento para armonizar la valoración de elementos del patrimonio geológico. ZUBIA 1997, 15, 11-20.

45. Rivas, V.; Rix, K.; Frances, A.; Cendrero, A.; Brunsden, D. Geomorphological indicators for environmental impact assessment: Consumable and non-consumable geomorphological resources. Geomorphology 1997, 18, 169-182. [CrossRef]

46. Coratza, P.; Giusti, C. Methodological proposal for the assessment of the scientific quality of geomorphosites. Il Quat. Ital. J. Quat. Sci. 2005, 18, 303-313.

47. Bruschi, V.M.; Cendrero, A. Geosite evaluation: Can we measure intangible values? Il Quat. Ital. J. Quat. Sci. 2005, 18, 293-306.

48. Bruschi, V.M.; Cendrero, A. Direct and parametric methods for the assessment of geosites and geomorphosites. In Geomorphosites; Reynard, E., Coratza, P., Regolini-Bissig, G., Eds.; Pfeil: München, Germany, 2009; pp. 73-88.

49. Serrano, E.; González-Trueba, J.J. Assessment of geomorphosites in natural protected areas: The Picos de Europa National Park (Spain). Géomorphologie 2005, 3, 197-208. [CrossRef]

50. Reynard, E.; Fontana, G.; Kozlik, L.; Scapozza, C. A method for assessing the scientific and additional values of geomorphosites. Geogr. Helv. 2007, 62, 148-158. [CrossRef]

51. Pererira, D.I.; Pereira, P.; Brilha, J.; Cunha, P.P. The Iberian Massif Landscape and Fluvial Network in Portugal: A geoheritage inventory based on the scientific value. Proc. Geol. Assoc. 2015, 126, 252-265. [CrossRef]

52. Brilha, J. Inventory and quantitative assessment of geosites and geodiversity sites: A review. Geoheritage 2016, 8, 119-134. [CrossRef]

53. Reynard, E.; Perret, A.; Bussard, J.; Grangier, L.; Martin, S. Integrated Approach for the Inventory and Management of Geomorphological Heritage at the Regional Scale. Geoheritage 2016, 8, 43-60. [CrossRef]

54. Pralong, J.P. A method for assessing the tourist potential and use of geomorphological sites. Géomorphologie 2005, 3, 189-196. [CrossRef]

55. Kubalíková, L. Geomorphosite assessment for geotourism purposes. Czech J. Tour. 2013, 2, 80-104. [CrossRef]

56. Zouros, N. Geomorphosite assessment and management in protected areas of Greece. Case study of the Lesvos Island-coastal geomorphosites. Geogr. Helv. 2007, 62, 69-180. [CrossRef]

57. Feuillet, T.; Sourp, E. Geomorphological heritage of the Pyrenees National Park (France): Assessment, Clustering, and Promotion of Geomorphosites. Geoheritage 2011, 3, 151-162. [CrossRef] 
58. Pellitero, R.; González-Amuchastegui, M.J.; Ruiz-Flaño, P.; Serrano, E. Geodiversity and Geomorphosite Assessment Applied to a Natural Protected Area: The Ebro and Rudron Gorges Natural Park (Spain). Geoheritage 2011, 3, 163-174. [CrossRef]

59. Comănescu, L.; Nedelea, R.; Dobre, R. The Evaluation of Geomorphosites from the Ponoare Protected Area. Studii și Cercetări de Geografie și Protecția Mediului 2012, 11, 54-61. [CrossRef]

60. Coratza, P.; Galve, J.P.; Soldati, M.; Tonelli, C. Recognition and assessment of sinkholes as geosites: Lessons from the Island of Gozo (Malta). Quaest. Geogr. 2012, 31, 25-35. [CrossRef]

61. Reynard, E. Protecting Stones: Conservation of erratic blocks in Switzerland. In Dimension Stone 2004. New Perspectives for a Traditional Building Material; Prykril, R., Ed.; A.A. Balkema Publishers: Leiden, The Netherlands, 2004; pp. 3-7.

62. Reynard, E. Géomorphosites et paysages. Géomorphologie 2005, 3, 181-188. [CrossRef]

63. Pelfini, M.; Bollati, I. Landforms and geomorphosites ongoing changes: Concepts and implications for geoheritage promotion. Quaest. Geogr. 2014, 33, 131-143. [CrossRef]

64. Reynard, E.; Coratza, P. The importance of mountain geomorphosites for environmental education. Examples from the Italian Dolomites and the Swiss Alps. Acta Geogr. 2016, 56, 291-303. [CrossRef]

65. Brilha, J. Geoheritage: Inventories and evaluation. In Geoheritage: Assessment, Protection and Management; Reynard, E., Brilha, J., Eds.; Elsevier: Amsterdam, The Netherlands, 2018; pp. 69-86.

66. Goudie, A.S. Aesthetics and relevance in geomorphological outreach. Geomorphology 2004, 47, $245-249$. [CrossRef]

67. Migoń, P. Stories behind superlative scenery. World Herit. 2012, 63, 18-25.

68. Różycka, M.; Migoń, P. Customer-Oriented Evaluation of Geoheritage-On the Example of Volcanic Geosites in the West Sudetes, SW Poland. Geoheritage 2018, 10, 23-37. [CrossRef]

69. Božić, S.; Tomić, N.; Pavić, D. Canyons as a potential geotourism attractions of Serbia-Comparative analysis of Lazar and Uvac canyons by using M-GAM model. Acta Geoturist. 2014, 5, 18-30.

(C) 2018 by the authors. Licensee MDPI, Basel, Switzerland. This article is an open access article distributed under the terms and conditions of the Creative Commons Attribution (CC BY) license (http:/ / creativecommons.org/licenses/by/4.0/). 